\title{
Interactive comment on "Basal sliding of temperate basal ice on a rough, hard bed: pressure melting, creep mechanisms and implications for ice streaming" by $M$. Krabbendam
}

\section{Krabbendam}

mkrab@bgs.ac.uk

Received and published: 5 May 2016

Reply to interactive comment by Olaf Eisen 'Update of literature and discussion needed'

Thank you for pointing out the paper by Christianson et al. (2014); it is really interesting, and I shall, in the revised version, indeed discuss their paper. Christianson et al. (2014) note that the bright radar reflectivity points to a thawed bed with significant water flow beneath the main trunk of the NEGIS, and that the bed is rough, so there is agreement on these issues.

The problem with many subsurface geophysical methods is that they generally do not 
provide unique solutions. The seismic properties of temperate ice, say with a water content of $1-3 \%$, were not discussed by Christianson et al. (2014), so the reader cannot judge whether the lower P-wave and S-wave velocities (which constitute the actual observations) are unique indicators for dilatant till, or that they may be explained by some other material. Could many of the geophysical observations by Christianson et al. (2014) not (also) be explained by the presence of a layer of temperate ice? Certainly Peters et al. (2012) show a very strong seismic attenuation (or: a low seismic $\mathrm{Q})$ near the melting point, which suggests a much lower P-wave velocity in temperate ice.

A problem with 'deforming till' is that it will continually move downstream with the ice, so it needs to be replenished by erosion upstream in order to sustain ice streaming, if deforming till was the main rate-controlling factor. Christianson et al. (2014) suggest as potential sources:

(A) 'geothermally altered rocks', related to the area of high geothermal heat flux, invoked by Fahnestock et al. (2001) to explain the very high basal melting rates they deduced. As discussed in the Manuscript, Fahnestock et al. (2001) did not take frictional heating into account, so the existence of such a geothermal high needs to be questioned. Apart from this, what rocks are we talking about here, and why would they produce more till?

(B) Reworking of ice-marginal deposits left over from a previous glaciation. This begs the question why such deposits were so concentrated in one place. Furthermore, typically Pleistocene deglaciated crystalline basement areas (e.g. Laurentide and Fennoscandian ice sheets) have experienced similar glaciation/deglaciation cycles, and thus could have similar ice-marginal deposits left from previous glaciations. However, where warm-based ice conditions are known to have prevailed, till is absent or patchy at best (see Manuscript for references).

Furthermore, given the observed roughness, with bedrock humps several 10s of me- 
tres high (Christianson et al. 2014), it should be noted that a deformable till will as such not help in moving ice over/around bedrock obstacles, unless the till covers these obstacles, which they do not seem to do. In short, the presence of a deformable till as a rate controlling factor below the NEGIS is by no means proven. Instead, the high melting rates deduced by Fahnestock et al. (2001) are very likely to lead to the production of a basal temperate layer of significant thickness.

Having said all this, it is of course possible that pockets and smears of till do exist below the NEGIS and that this is overlain by a temperate ice layer - deformable till and basal temperate ice are not mutually exclusive. The main purpose of discussing the NEGIS in the Discussion is to try to make other researchers think about, and check the possibility of, the potential existence of a basal temperate ice layer below modern and ancient ice streams.

\section{References:}

Christianson, K., Peters, L. E., Alley, R. B., Anandakrishnan, S., Jacobel, R. W., Riverman, K. L., Muto, A., and Keisling, B. A.: Dilatant till facilitates ice-stream flow in northeast Greenland, Earth and Planetary Science Letters, 401, 57-69, doi: 10.1016/j.epsl.2014.05.060, 2014.

Fahnestock, M., Abdalati, W., Joughin, I., Brozena, J., and Gogineni, P.: High geothermal heat flow, basal melt, and the origin of rapid ice flow in central Greenland., Science, 297, 2338-42, doi: 10.1126/science.1065370, 2001.

Peters, L. E., Anandakrishnan, S., Alley, R. B., and Voigt, D. E.: Seismic attenuation in glacial ice: A proxy for englacial temperature, Journal of Geophysical Research: Earth Surface, 117, F02008, doi:10.1029/2011JF002201, 2012.

Interactive comment on The Cryosphere Discuss., doi:10.5194/tc-2016-52, 2016. 